\title{
BREVE REFERENCIA A LA STJUE DE 21 DE NOVIEMBRE DE 2018
}

\author{
Francisco Ramón Lacomba Pérez
}

Abogado del Área de Conocimiento e Innovación de Cuatrecasas

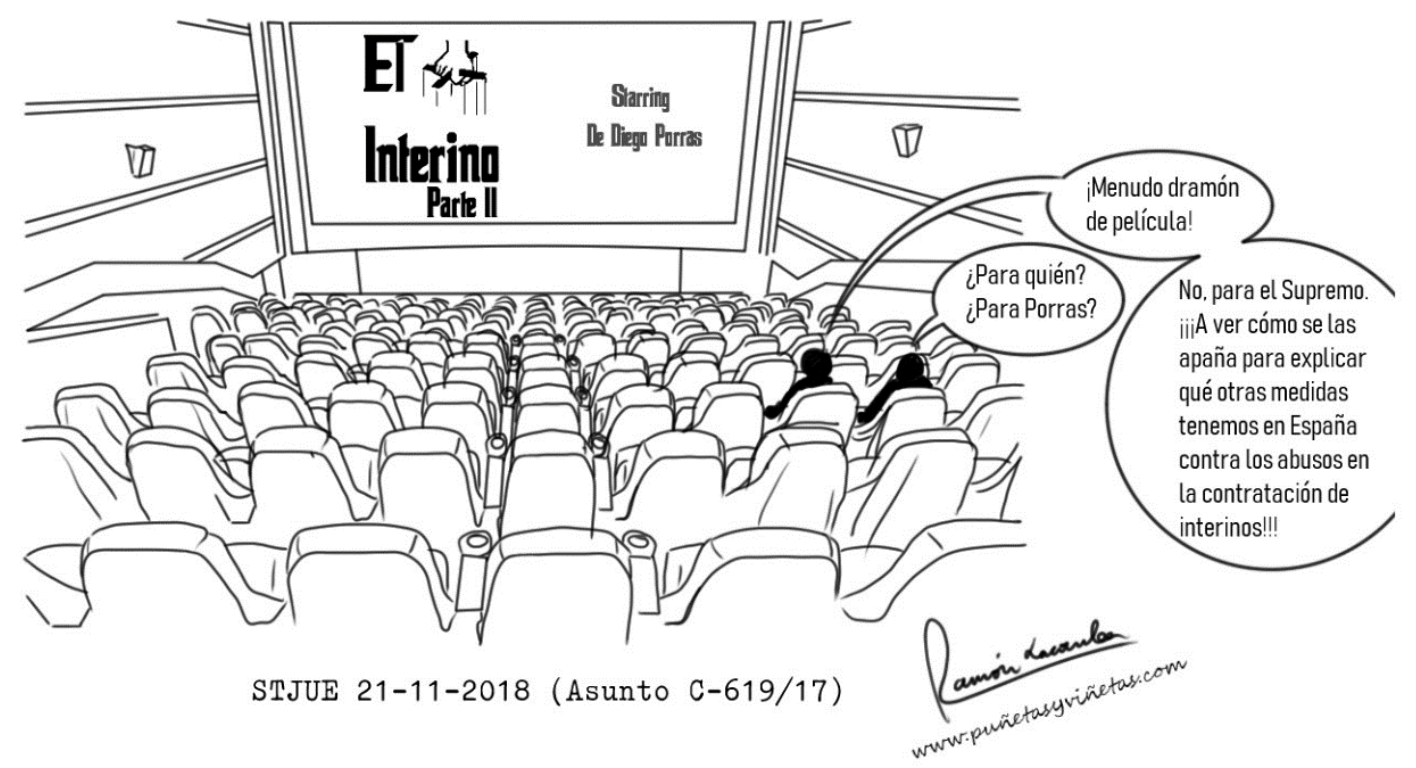

En la Sentencia del Tribunal de Justicia de la Unión Europea (TJUE) de 21 de noviembre de 2018 (asunto C-619/17), la Sala somete por segunda vez la extinción de la trabajadora interina, De Diego Porras, al test de la Directiva 1999/70/CE del Consejo, de 28 de junio de 1999, relativa al Acuerdo Marco de la CES, la UNICE y el CEEP sobre el trabajo de duración determinada. Ya lo hizo anteriormente, con bastante poca fortuna, en la STJUE de 14 de septiembre de 2016 (asunto C-596/14), donde declaró, sin especial esfuerzo de fundamentación, que carecía de razón objetiva negar al trabajador interino el derecho a la indemnización por fin de su contrato temporal y sí concedérsela, en cambio, a los "trabajadores fijos comparables" al término de su contrato por despido objetivo, lo que vulneraba el principio de no discriminación.

En esta segunda Sentencia, más meditada, la Sala rectifica, y confirma una vez más, como ya anticipó en el Caso Montero Mateos (STJUE 5 de junio de 2018, asunto C677/16), que sí concurre una razón objetiva que justifica la diferencia de trato entre la extinción del contrato de interinidad por reincorporación del titular del puesto o cobertura de la vacante, y la extinción del contrato de un trabajador fijo por causas objetivas del artículo 52 ET. Concretamente, en el caso de la extinción de un contrato de duración determinada finalizado por las causas de temporalidad que se 
pactaron, las partes conocen, desde el momento de su celebración, la fecha o el acontecimiento que determina su finalización. En cambio, la extinción de un contrato fijo por una de las causas previstas en el artículo 52 ET, a iniciativa del empresario, tiene lugar al producirse circunstancias que no estaban previstas en el momento de su celebración y que suponen un cambio radical en el desarrollo normal de la relación laboral.

Por tanto, la ausencia de indemnización por finalización del contrato de interinidad no se opone a la normativa comunitaria, a lo que añade, además, la Sala que la indemnización por fin de contrato temporal no es una medida adecuada ni suficiente para sancionar el uso abusivo de contratos temporales (lo cual es un claro mensaje al legislador español para que revise su modelo de contratación temporal, que precisamente lucha contra el abuso de la temporalidad a través de una indemnización de 12 días de salario por año trabajado por fin de contrato: artículo 49.1.c ET). Pero, sí se opondría, en cambio, al Derecho de la Unión que no existan en el ordenamiento jurídico español otras medidas para evitar y sancionar el uso abusivo de la interinidad, lo que deja a la comprobación del Tribunal español.

Deberá, por tanto, el Tribunal Supremo pronunciarse sobre el particular, señalando qué otras medidas (alternativas a la indemnización) existen en el ordenamiento español que eviten y sancionen el abuso en la contratación de interinos. Habrá que esperar al pronunciamiento de la Sala IV. 